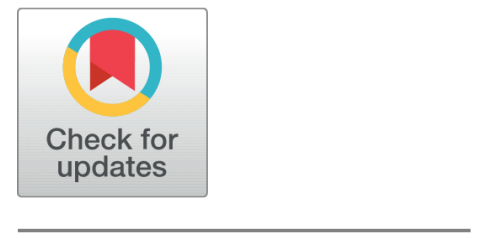

6 OPEN ACCESS

Received: 17-06-2020

Accepted: 08-07-2020

Published: 27-07-2020

Editor: Dr. Natarajan Gajendran

Citation: Memon FA, Shah S, Khoso IU (2020) Role of leadership communication in creating change readiness: revisiting Kurt Lewin's Model in telecommunication sector of Pakistan. Indian Journal of Science and Technology 13(26): 2625-2632. https://doi.org/ 10.17485/IJST/v13i26.933

* Corresponding author. Farzana Akmal Memon

1 Institute of Business Administration, University of Sindh Jamshoro, Pakistan

farzanamemon7@gmail.com

Funding: None

Competing Interests: None

Copyright: ( 2020 Memon, Shah, Khoso. This is an open access article distributed under the terms of the Creative Commons Attribution License, which permits unrestricted use, distribution, and reproduction in any medium, provided the original author and source are credited.

Published By Indian Society for Education and Environment (iSee)

\section{Role of leadership communication in creating change readiness: revisiting Kurt Lewin's Model in telecommunication sector of Pakistan}

\author{
Farzana Akmal Memon ${ }^{1}{ }^{*}$, Sobia Shah ${ }^{1}$, Imam Uddin Khoso' \\ 11 Institute of Business Administration, University of Sindh Jamshoro, Pakistan
}

\section{Abstract}

Objective : The purpose of present study is to investigate the relationship between Change Communication and employees' readiness for change. Additionally, the study has attempted to address the mediating effect of employees trust on Change communication - employees' readiness relationship. Furthermore, the study reports the moderating effect of employees' openness on relationship between Change communication and employees trust. Method: Data collected from employees of telecommunication sector in Pakistan i.e PTCL, Ufone, Mobilink, Telenor undergoing through structural change. A two-step method to partial least square- structural equation modeling used in the study. Findings: Testing the Kurt Lewin theory of change providing empirical evidence on the hypothesized relationships found that communication was positively associated with employee readiness. However, employee trust mediates this link. The relationship between communication and trust depends on higher levels of employee openness to change. Novelty: This study will be among few studies that have highlighted the importance of change communication in developing trust by removing fears and uncertainties and making employees ready to accept the change during mergers, acquisitions and divestitures using the lens of Lewin's three-step model.

Keywords: Change communication; openness to change; trust in leadership; readiness for change

\section{Introduction}

Technology-based organizations such as telecommunication firms now-a-days are facing changes due to various environmental factors ${ }^{(1)}$. However, the failure rate of organizational changes is high due to the leaders' failure to manage human side of organizations ${ }^{(2)}$. A recent study by employing literature search, interviews and the survey and collecting data from diverse change backgrounds have found that effective change communication is the key to manage and implement change successfully ${ }^{(3)}$. The literature suggests that it is not inherent 
to individuals' minds to oppose the change rather employee do it due to the way it is imposed on them or communicated to them ${ }^{(4)}$. The theory of Entertainment Persuasion ${ }^{(5)}$ suggests that when leaders communicate to the followers through prosocial and para social interaction, it helps mitigate resistance and enhance readiness for change. Choi \& Ruona ${ }^{(6)}$ reviewed literature on individual change readiness and suggested that change communication is the most important factor that creates change readiness.

A recent study from Indonesian technology context has found a positive link between change communication and change readiness. They suggested testing this relationship in other Asian countries specifically in technology sector. This study therefore intends to test a comprehensive model of determinants of readiness for change in telecommunication sector in Pakistan. This study believes that when leaders communicate effectively, they are able to garner trust of employees, which in turn generate positive behaviors of readiness for change. However, this impact of change communication on trust will depend upon employees' level of openness, that is, higher level of change communication strongly related to trust when employees are high on openness. This study will be among few studies that have highlighted the importance of change communication in developing trust by removing fears and uncertainties and making employees ready to accept the change using the lens of Lewin's three-step model.

In an extremely global and demanding environment, the extraordinary practice of technology has enforced telecommunication sector of Pakistan to get involve in structural changes which has become emergent due to their increased revenue. In Pakistan telecom sector is the second largest sector that is involved in structural changes after the banking sector where companies merge and acquires to grab the large number of shares in the market ${ }^{(7)}$. In present study, the functionality or the desirability of the organizational restructuring is not propaganda instead present study discusses the correspondence between the use and perceived quality of management communication about the organizational change and employees' individual responses to organizational change that ultimately result in implementing change successfully within the organization.

Research on change management has overly emphasized on leadership styles and their effectiveness in different settings. Different authors have tested different leadership styles to either generate support for change ${ }^{(8)}$ commitment to change ${ }^{(9)}$ readiness for change ${ }^{(10)}$ or to mitigate resistance to change ${ }^{(11)}$ and cynicism about change ${ }^{(12)}$. However, there are few studies that have combined leadership and communication to develop change oriented behavior ${ }^{(13,14)}$. There are again some researchers who feel the need to test specific behaviors of leaders such as knowledge sharing ${ }^{(11)}$, coaching and communication to see its effect on developing employee change supportive behaviors ${ }^{(15)}$. This study thus builds upon the classical planned change model of Kurt Lewin and tests how change related communication may unfreeze the statuesque by developing employees' trust and fostering change readiness (refreezing). This study thus fills the theoretical and practical gap in research to provide sound theoretical base for communication and its impact on change readiness in a most dynamic sector of today's environment i.e. telecommunication sector.

\section{Hypothesis Development}

\section{Change communication and Trust in Leadership}

Communication is any information that is revealed either face to face or through any channel ${ }^{(16)}$. For achieving a well-managed and successful change, communication is the most responsive element ${ }^{(17)}$. Trust is an important construct which has been widely discussed in organizational behavior research in a variety of forms and frameworks ${ }^{(18)}$. Matos Marques Simoes \& Esposito ${ }^{(19)}$ detailed that the communication is an important component in building the change readiness, reducing the insecurities (Employee's Trust) and developing the stakeholder's commitment (employee's readiness). Arnaout \& Esposito ${ }^{(20)}$ also advocate that communication helps mitigate the negative consequences of uncertainties during change and help garnering support for change initiatives during turbulent environments (structural change). Therefore, the present study proposed the following hypothesis

H1: Change Communication is positively associated with Employee's Trust

Employee's trust and Employee's Readiness for change 
Employee's readiness for change is shaped by an interchange between feelings of uncertainty caused by the stress resulting from change, and the resources open to increase control over the indeterminate character of change ${ }^{(21)}$. Rafferty \& Jimmieson ${ }^{(22)}$ indicated that the reason for failure of implementing change within organization is that employees are not ready to accept the change. Leadership and management approaches to change has significant effect on the reactions of an individual employee ${ }^{(23)}$. Armenakis \& Harris ${ }^{(24)}$ identified the role of employee's trust in creating the employee's readiness towards change within organization. Similarly, ${ }^{(25)}$ indicated that level of trust between management and employees is the strongest factor for accepting change or employee's readiness to implement change within organization. Therefore, the present study proposed the following hypothesis.

H2: Employee's Trust is positively associated with Employee's Readiness for change

\section{Mediating role of trust in Leadership}

Stahl \& Stitkin ${ }^{(26)}$ indicated that during and after the change, it is only change communication that can help an employee to deal with employee's uncertainty. Change communication can help effect the employee's trust ${ }^{(27)}$ and ultimately an employee is ready to accept the change. Employee's acceptance and rejection to change is related to the employee's level of trust on management which can be achieved by clear and transparent communication ${ }^{(28)}$. Oreg \& Vakola ${ }^{(29)}$ also establish a positive relationship between employees trust and readiness for organizational change which can be achieved through communication. Eby \& Adams ${ }^{(30)}$ indicated that employees trust can aid in to decrease their concerns and make the changed environment comfortable. Based on the literature, it could be contended that communication is an essential background means that can assist employees to better cope with the stress caused due to organizational change. Therefore, the present study proposed the following hypothesis.

H3: Employee's trust mediates the relationship between change communication and employee's readiness for change

\section{Openness as a Moderator}

Openness refers to an individual personality trait that reflects a person's ability to pursue, find, understand, use and acknowledge dynamic aspects of abstract information as well as the information that can be easily measured and objectified (McCrae, 1993). Erwin \& Garman ${ }^{(31)}$ correlated employees who are open and ready to alter their behaviors can bring an achievement to the planned organizational changes. Employees' resistance to change can be overcome by increasing the receptive power of employees which can be achieved by change communication from the leaders in order to generate employee's trust ${ }^{(32)}$. Employees with a high degree of openness marks more trust in top management and feel that they will not be targeted negatively as they actually are open to believe that intentions of top management is trustworthy ${ }^{(33)}$. According to Blau ${ }^{(34)}$ an increase in trust in the supervisor would ultimately enhance employees' aspiration to respond to the organization. Change readiness is the best mode to implement change within organization ${ }^{(35)}$.

H4: The positive relationship between change communication and employees trust in leadership will be stronger when employee's openness is higher.

Figure 1 demonstrate the conceptual framework of the present study highlighting the relationship between four variables.

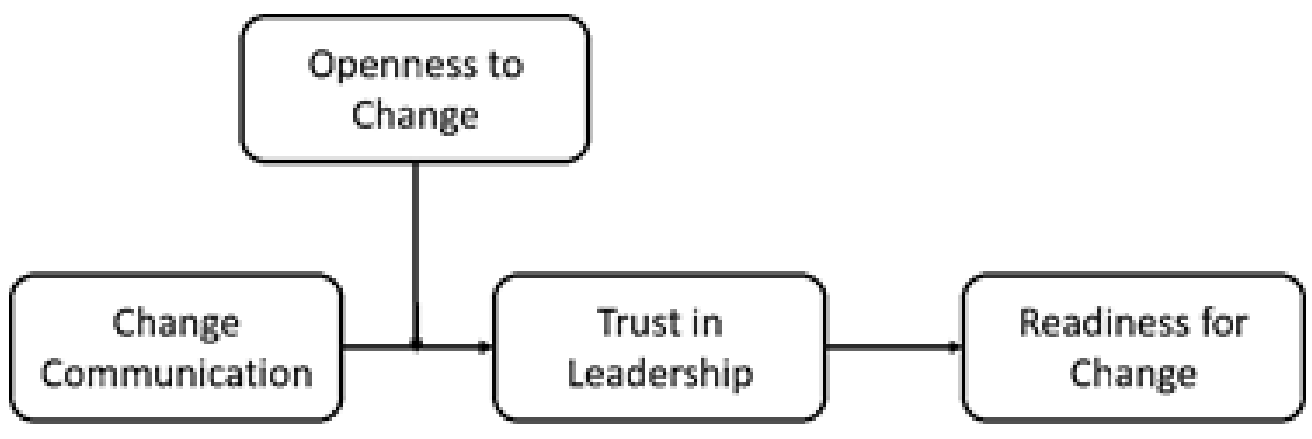

Fig 1. Conceptual Framework 


\section{Methodology}

Data collected from 442 employees of telecommunication companies of Pakistan which are undergoing through structural change (merger, acquisition \& divestiture) using the stratified sampling technique. Scales were adopted from the study of Bouckenogooghe \& Devos ${ }^{(36)}$ and Employee's Openness to change scale was adapted from the work of Susskind Miller \& Johnson ${ }^{(37)}$.

\section{Data Analysis}

Results of measurement model from Table 1 indicate that values of outer loadings $(>0.60)$, Average variance extracted ( $>0.5$ ), composite reliability $(>0.7)$ surpass the cut off value thus establishes indicator reliability, internal consistency reliability and convergent validity respectively ${ }^{(38,39)}$. The study also found discriminant validity based on the multi trait-multimethod matrix ${ }^{(40)}$. All the HTMT values are less than 0.85 ( Table 2) indicating that the discriminant validity ascertained. ${ }^{(41)}$.

Table 1. Outer Loadings, Composite Reliability andAverage Variance Extracted

\begin{tabular}{|c|c|c|c|c|}
\hline Construct & Items & Outer Loadings & CR & AVE \\
\hline \multirow{6}{*}{ Change Communication } & $\mathrm{CC} 1$ & 0.884 & \multirow{6}{*}{0.951} & \multirow{6}{*}{0.763} \\
\hline & CC2 & 0.903 & & \\
\hline & $\mathrm{CC} 3$ & 0.905 & & \\
\hline & $\mathrm{CC} 4$ & 0.857 & & \\
\hline & CC5 & 0.827 & & \\
\hline & CC6 & 0.865 & & \\
\hline \multirow{5}{*}{ Employee's Readiness for Change } & ERC1 & 0.706 & \multirow{5}{*}{0.932} & \multirow{5}{*}{0.733} \\
\hline & ERC2 & 0.894 & & \\
\hline & ERC3 & 0.893 & & \\
\hline & ERC4 & 0.906 & & \\
\hline & ERC5 & 0.866 & & \\
\hline \multirow{4}{*}{ Employee's Openness to Change } & EOC1 & 0.719 & \multirow{4}{*}{0.874} & \multirow{4}{*}{0.634} \\
\hline & EOC2 & 0.804 & & \\
\hline & EOC3 & 0.870 & & \\
\hline & EOC4 & 0.786 & & \\
\hline \multirow{5}{*}{ Employee's Trust in Leadership } & ETL1 & 0.741 & \multirow{5}{*}{0.916} & \multirow{5}{*}{0.686} \\
\hline & ETL2 & 0.878 & & \\
\hline & ETL3 & 0.874 & & \\
\hline & ETL4 & 0.857 & & \\
\hline & ETL5 & 0.782 & & \\
\hline
\end{tabular}

Table 2. Discriminant Validity

\begin{tabular}{llll}
\hline Construct & 1 & 2 & 3 \\
\hline Change Communication_ & & & \\
Employee's Openness to Change & 0.622 & & \\
Employee's Readiness for Change & 0.624 & 0.740 & 0.739 \\
Employee's Trust in Leadership & 0.722 & 0.600 & \\
\hline
\end{tabular}


For structural model, present study, employed bootstrapping method with 5000 resamples using Bias-Corrected and Accelerated (BCa) Bootstrap with one-tailed and significance level 0.05. Figure 2 displays structural model developed in SMART PLS.

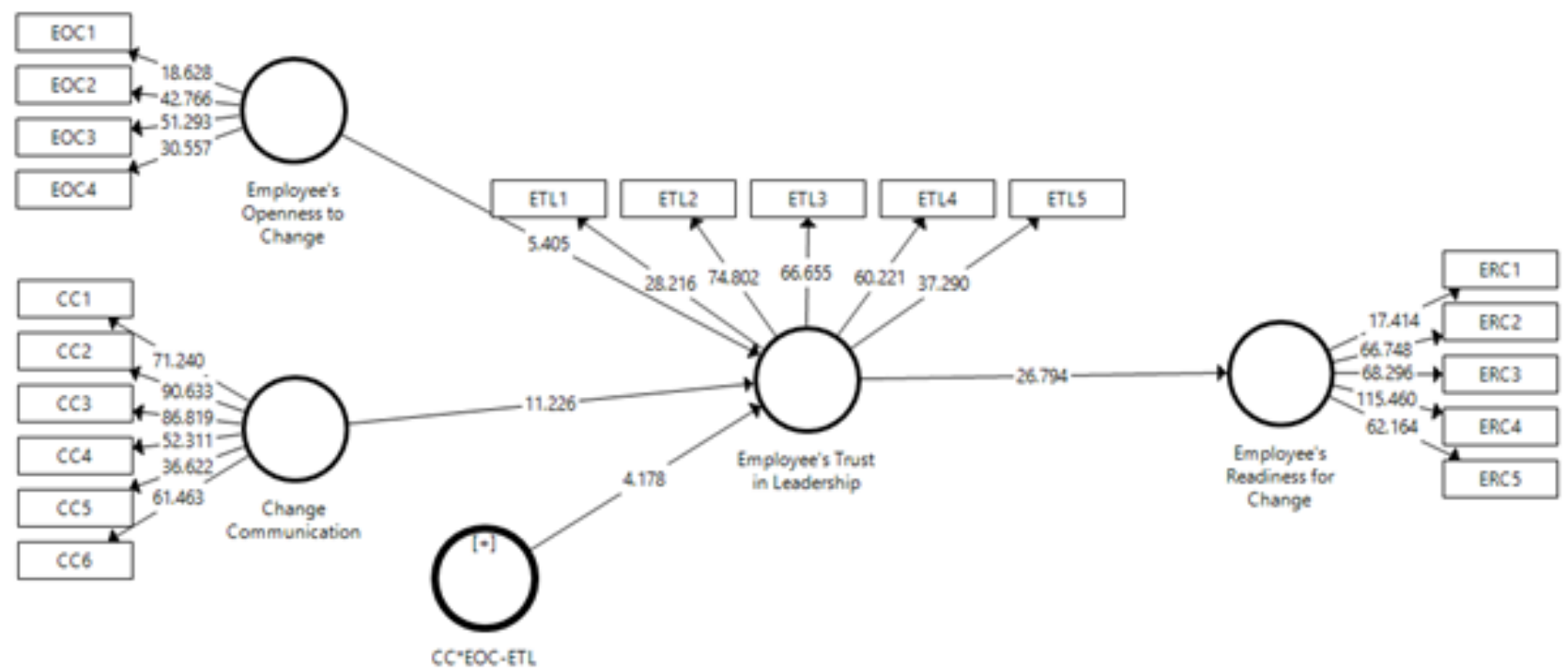

Fig 2. Structural Model- SMART PLS

Table 3 indicate that Change communication is positively associated with employee's trust $\beta=0.529$, $\mathrm{t}$-value $=11.755 \mathrm{p}<0.05$, CI $[0.448 ; 0.597]$. The value of $\mathrm{f}^{2}=0.371$ indicates strong effect size ${ }^{(42)}$. Employees trust is positively associated with employees' readiness $\beta=0.681$, t-value 27.906, $\mathrm{p}<0.05$, CI [0.637; 0.720]. the value of $\mathrm{f}^{2}=0.863$ indicates strong effect size. In order to test the mediation, ${ }^{(42)}$ method of bootstrapping the indirect effect of trust with $\beta=0.360$, $\mathrm{t}$-value $=10.138, \mathrm{p}<0.05$, CI $[0.301 ; 0.415$ indicating a mediating effect in the model hence supporting H3.

Table 3. Significance \& Relevance of PathCoefficients

\begin{tabular}{llllllllll}
\hline & Relationship & $\beta$ & Std Error & T Value & P Value & LCI (5\%) & $\begin{array}{l}\text { UCI } \\
(95 \%)\end{array}$ & $f^{2}$ & Accepted \\
\hline H1 & CC à ETL & 0.529 & 0.045 & 11.755 & 0.000 & 0.448 & 0.597 & 0.371 & Yes \\
H2 & ETL à ERC & 0.681 & 0.024 & 27.906 & 0.000 & 0.637 & 0.720 & 0.863 & Yes \\
H3 & CCà ETLà ERC & 0.360 & 0.036 & 10.138 & 0.000 & 0.301 & 0.415 & - & Yes \\
H4 & CCEOCà ETL & 0.131 & 0.032 & 4.145 & 0.000 & 0.082 & 0.191 & 0.037 & Yes \\
\hline
\end{tabular}

Moderating effect of employees' openness ${ }^{(43)} \beta=0.131$, $t$-value $=4.145$, CI [0.082;0.191] indicating a synergistic moderating effect of employees' openness. Through interaction plot ( Figure 3), Dawson (2014) indicate the relationship between change communication and employees trust was stronger when employee's openness was higher, whereas low employees openness had no impact on change communication and employees trust relationship.

The model explains $49.4 \%$ of total variance in employees trust and $46.3 \%$ of total variance in employees readiness hence it shows that two endogenous variable exhibited moderate level of R-square ${ }^{(44)}$. The model indicate that the predictive relevance within sample of the model $\mathrm{ETL}=0.318 \& \mathrm{ERC}=0.315$ as the $\mathrm{Q}$ square values are above zero ${ }^{(45)}$. Holdout samples indicate strong predictive power of indicators RMSE, PLS-LM (ERD1 $=-0.189$, ERD2 $=-0.107$, $\mathrm{ERD} 3=-0.029 \mathrm{ERD} 4=-0.029 \mathrm{ERD} 5=-0.010)$ as $\mathrm{PLS}<\mathrm{LM}$. 


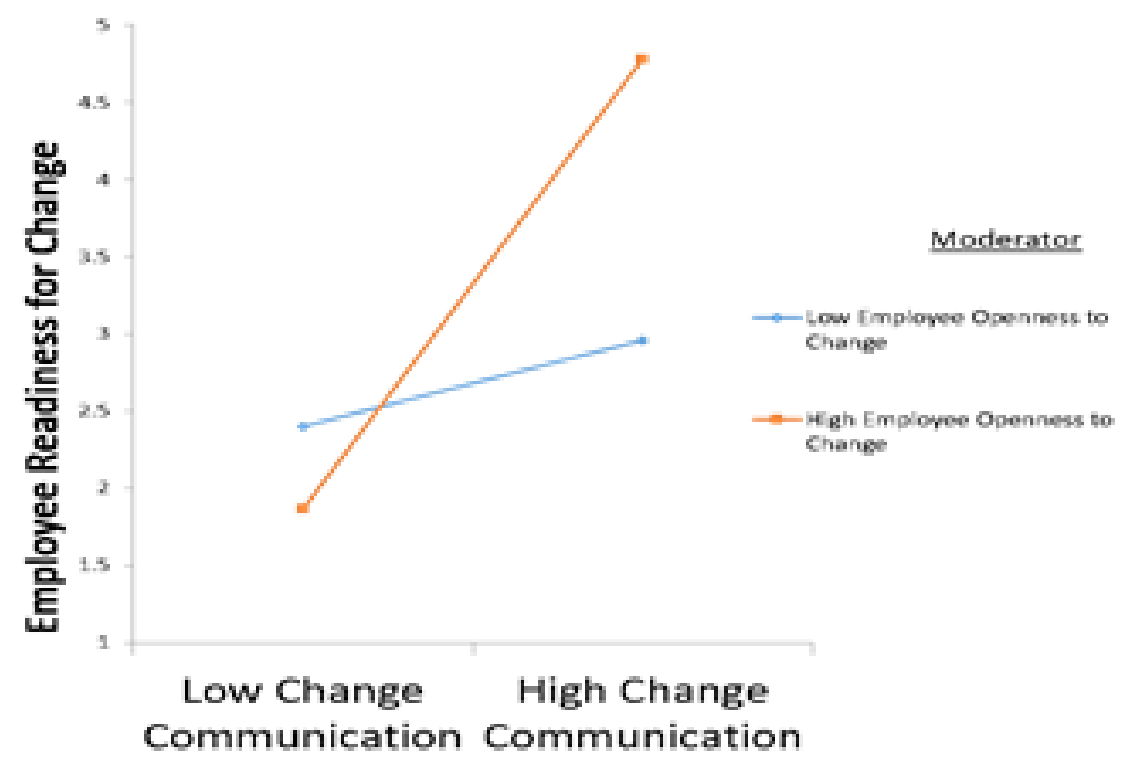

Fig 3. Interaction Plot

\section{Discussion}

First hypothesis found a positive relationship between change communication and employee trust. This finding is in line with the established fact that effective and relevant communication at times of crises such as organizational (structural ) change creates an environment of safety and trust leading to adaptation to change more successful ${ }^{(46)}$.

Second hypothesis related to relationship between trust and readiness for change. This study support for this relationship too. This finding is also at par with literature as Zayim \& Kondakci ${ }^{(47)}$ found support for positive association between trust and readiness for change. Bakari \& Hunjra ${ }^{(8)}$ also found that employee trust in management support will create readiness for organizational change.

Third hypothesis stated that trust mediate the relationship between change communication and readiness for change. This hypothesis supported by empirical findings and Literature also supports this notion that when change communicated effectively and information regarding change disseminated fairly, it will foster employee trust that will further develop employee readiness for change.

Fourth and very important hypothesis of this study was about moderating role of openness to change between change communication and trust in leadership. Openness to change is relatively new construct and it is gaining popularity as a separate construct having distinct effects. Wanberg \& Banas ${ }^{(48)}$ explored causes and consequences of openness to change. They found that communication package containing information related to change and employee participation in decision-making strongly related to higher levels of employee openness to change. Present study has found that relationship between communication and trust will be dependent upon employee openness such that this relationship will be stronger when employees are high on openness rather than low.

\section{Conclusion and Future Recommendation}

This study tested role of change communication in the development of readiness for organizational change. Utilizing classical three-step model of Lewin, this study found support for the notion that change commination may serve as groundbreaking force that not only breaks the statuesque but creates an environment of trust which further leads towards employee readiness for change. This study has also found the boundary conditions in relationship between change communication and trust, that is, level of employee openness to change. 
As current era is fourth industrial revolution, where technology has become prominent to organizational success and means of digital communication are gaining importance. Present study suggest future researchers to elaborate opportunities to integrate digital tools for communication of employees and managers and a way in which leaders can benefit from using digital communication platforms during organizational change as digitalization brings decentralization, collaboration, crowdsourcing, connectivity, mobility and ongoing communication to the workplace.

\section{References}

1) Ashmarina S, Kandrashina E, Dorozhko JA. Digitalization as a source of transformation of value chains of telecommunication companies using the example of PAO megaphone. In: and others, editor. Digital Transformation of the Economy: Challenges, Trends and New Opportunities. Springer. 2020;p. 581-590.

2) Cinite I, Duxbury LE. Measuring the Behavioral Properties of Commitment and Resistance to Organizational Change. The Journal of Applied Behavioral Science. 2018;54(2):113-139. Available from: https://dx.doi.org/10.1177/0021886318757997.

3) Christensen M. Communication as a Strategic Tool in Change Processes. International Journal of Business Communication. 2014;51(4):359-85.

4) Knowles ES, Linn JA. The Importance of Resistance to Persuasion. In: Resistance and persuasion. Mahwah, NJ: Lawrence Erlbaum. 2004;p. 3-9.

5) Moyer-Gusé E. Toward a Theory of Entertainment Persuasion: Explaining the Persuasive Effects of Entertainment-Education Messages. Communication Theory. 2008;18(3):407-425. Available from: https://dx.doi.org/10.1111/j.1468-2885.2008.00328.x.

6) Choi M, Ruona WEA. Individual Readiness for Organizational Change and Its Implications for Human Resource and Organization Development. Human Resource Development Review. 2011;10(1):46-73. Available from: https://dx.doi.org/10.1177/1534484310384957.

7) Kanwal A, Ahmad N, Majid M, Nadeem M. The Efficiency of Merger and Acquisition in Telcom Sector of Pakistan. Singaporean Journal of Business, Economics and Management Studies. 1122;51:1-12.

8) Bakari H, Hunjra AI, Niazi GSK. How Does Authentic Leadership Influence Planned Organizational Change? The Role of Employees' Perceptions: Integration of Theory of Planned Behavior and Lewin's Three Step Model. Journal of Change Management. 2017;17(2):155187. Available from: https://dx.doi.org/10.1080/14697017.2017.1299370.

9) Hill NS, Seo MG, Kang JH, Taylor MS. Building Employee Commitment to Change Across Organizational Levels: The Influence of Hierarchical Distance and Direct Managers' Transformational Leadership. Organization Science. 2012;23(3):758-777. Available from: https://dx.doi.org/10.1287/orsc.1110.0662.

10) Akca M, Strategic, Leadership. Readiness for Change, and Innovative Work Behavior. Strategy and Superior Performance of Micro and Small Businesses in Volatile Economies. Advances in Logistics, Operations, and Management Science2019;p. 57-77.

11) Hussain ST, Lei S, Akram T, Haider MJ, Hussain SH, Ali M. Kurt Lewin's change model: A critical review of the role of leadership and employee involvement in organizational change. Journal of Innovation \& Knowledge. 2018;3(3):123-127. Available from: https: //dx.doi.org/10.1016/j.jik.2016.07.002.

12) Bakari H, Hunjra AI, Jaros S, Khoso I. Moderating role of cynicism about organizational change between authentic leadership and commitment to change in Pakistani public sector hospitals. Leadership in Health Services. 2019;32(3):387-404. Available from: https://dx.doi.org/10.1108/lhs-01-2018-0006.

13) PORTOGHESE I, GALlETTA M, BATTISTELli A, SAIANI L, PENNA MP, ALLEGRINI E. Change-related expectations and commitment to change of nurses: the role of leadership and communication. Journal of Nursing Management. 2012;20(5):582-591. Available from: https://dx.doi.org/10.1111/j.1365-2834.2011.01322.x.

14) Yue CA, Men LR, Ferguson MA. Bridging transformational leadership, transparent communication, and employee openness to change: The mediating role of trust. Public Relations Review. 2019;45(3):101779-101779. Available from: https://dx.doi.org/10.1016/j.pubrev. 2019.04.012.

15) Gilley A, Gilley JW, McMillan HS. Organizational change: Motivation, communication, and leadership effectiveness. Performance Improvement Quarterly. 2009;21:75-94. Available from: https://dx.doi.org/10.1002/piq.20039.

16) Bishop D. Children's Communication Checklist (CCC-2). In: Volkmar RF, et al., editors. Encyclopedia of Autism Spectrum Disorders. Springer. 2013.

17) Ocasio W, Loewenstein J, Nigam A. How Streams of Communication Reproduce and Change Institutional Logics: The Role of Categories. Academy of Management Review. 2015;40(1):28-48. Available from: https://dx.doi.org/10.5465/amr.2013.0274.

18) Dietz G, Hartog DND. Measuring trust inside organisations. Personnel Review. 2006;35(5):557-588. Available from: https://dx.doi.org/ 10.1108/00483480610682299.

19) Simoes PMM, Esposito M. Improving change management: how communication nature influences resistance to change. Journal of Management Development. 2014;33(4):324-341. Available from: https://dx.doi.org/10.1108/jmd-05-2012-0058.

20) Arnaout B, Esposito M. The value of communication in turbulent environments: how SMEs manage change successfully in unstable surroundings. International Journal of Entrepreneurship and Small Business. 2018;34(4):500-515. 
21) Bordia P, Hunt E, Paulsen N, Tourish D, DiFonzo N. Uncertainty during organizational change: Is it all about control? European Journal of Work and Organizational Psychology. 2004;13(3):345-365. Available from: https://dx.doi.org/10.1080/13594320444000128.

22) Rafferty AE, Jimmieson NL, Restubog S, Oreg S, Michel A, By RT, et al. When leadership meets organizational change: The influence of the top management team and supervisory leaders on change appraisals, change attitudes, and adjustment to change. In: Oreg S, Micheal A, By RT, et al., editors. The psychology of organizational change: Viewing change from the employee's perspective. Cambridge University Press. ;p. 145-172. Available from: https://doi.org/10.1017/CBO9781139096690.011.

23) Fugate M, Oreg S, Michel A, By RT. .

24) Armenakis AA, Harris SG, Mossholder KW. Creating Readiness for Organizational Change. Human Relations. 1993;46(6):681-703. Available from: https://dx.doi.org/10.1177/001872679304600601.

25) Reinke SJ. Does the Form Really Matter? SAGE Publications. 2003. Available from: https://dx.doi.org/10.1177/0734371x02250109. doi:10.1177/0734371x02250109.

26) Stahl GK, Sitkin SB. 2005.

27) Armenakis AA, Harris SG. Crafting a change message to create transformational readiness. Journal of Organizational Change Management. 2002;15(2):169-183. Available from: https://dx.doi.org/10.1108/09534810210423080.

28) Stevens GW. Toward a Process-Based Approach of Conceptualizing Change Readiness. The Journal of Applied Behavioral Science. 2013;49(3):333-360. Available from: https://dx.doi.org/10.1177/0021886313475479.

29) Oreg S, Vakola M, Armenakis A. Change Recipients' Reactions to Organizational Change. The Journal of Applied Behavioral Science. 2011;47(4):461-524. Available from: https://dx.doi.org/10.1177/0021886310396550.

30) Eby LT, Adams DM, Russell JEA, Gaby SH. Perceptions of Organizational Readiness for Change: Factors Related to Employees' Reactions to the Implementation of Team-Based Selling. Human Relations. 2000;53(3):419-442. Available from: https://dx.doi.org/10.1177/ 0018726700533006.

31) Erwin DG, Garman AN. Resistance to organizational change: linking research and practice. Leadership \& Organization Development Journal. 2010;31(1):39-56. Available from: https://dx.doi.org/10.1108/01437731011010371.

32) Smollan R, Parry K. Follower perceptions of the emotional intelligence of change leaders: A qualitative study. Leadership. 2011;7(4):435462. Available from: https://dx.doi.org/10.1177/1742715011416890.

33) Michaelis B, Stegmaier R, Sonntag K. Affective Commitment to Change and Innovation Implementation Behavior: The Role of Charismatic Leadership and Employees' Trust in Top Management. Journal of Change Management. 2009;9(4):399-417. Available from: https://dx.doi.org/10.1080/14697010903360608.

34) Blau PM. Exchange and power in social life. New York. John Wiley and Sons. 1964.

35) Antecedents of employee readiness for change: Mediating effect of commitment to change. 2015. Available from: http://www.msaes.org/ article_10100_1596.html.

36) Bouckenooghe D, Devos G, den Broeck HV. Organizational Change Questionnaire-Climate of Change, Processes, and Readiness: Development of a New Instrument. The Journal of Psychology. 2009;143(6):559-599. Available from: https://dx.doi.org/10.1080/ 00223980903218216.

37) Susskind AM, Miller VD, Johnson JD. Downsizing and structural holes: Their impact on layoff survivors' perceptions of organizational chaos and openness to change. Communication Research. 1998;25(1):30-65.

38) Hair JF, Ringle CM, Sarstedt M. Partial Least Squares Structural Equation Modeling: Rigorous Applications, Better Results and Higher Acceptance. Long Range Planning. 2013;46(1-2):1-12. Available from: https://dx.doi.org/10.1016/j.lrp.2013.01.001.

39) Hair JF, Hult GTM, Ringle CM, Sarstedt M. A primer on partial least squares structural equation modeling (PLS-SEM). 2nd ed. and others, editor. 2017.

40) Dijkstra TK, Henseler J. Consistent and asymptotically normal PLS estimators for linear structural equations. Computational Statistics \& Data Analysis. 2015;81:10-23. Available from: https://dx.doi.org/10.1016/j.csda.2014.07.008.

41) Kline RB. Convergence of Structural Equation Modeling and Multilevel Modeling. In: Williams M, Vogt WP, et al., editors. The SAGE Handbook of Innovation in Social Research Methods. 2011. Available from: https://dx.doi.org/10.4135/9781446268261.n31.

42) Wong KK. Partial least squares structural equation modeling (PLS-SEM) techniques using. SmartPLS Marketing Bulletin. 2013;24(1):132.

43) Henseler J, Fassott G, Vinzi VE, Chin WW, Henseler J, Wang H. Handbook of partial least squares. Handbook of partial least squares2010. 2010.

44) Chin WW. The partial least squares approach to structural equation modeling. Modern methods for business research. 1998;8(2):295-336.

45) Sarstedt M, Ringle CM, Henseler J, Hair JF. On the emancipation of PLS-SEM: A commentary on Rigdon. Long range planning. 2012;47(3):154-60.

46) Langer R, Thorup S. Building trust in times of crisis: Storytelling and change communication in an airline company. Corporate Communications: An International Journal. 2006;11(4):371-90.

47) Zayim M, Kondakci Y. An exploration of the relationship between readiness for change and organizational trust in Turkish public schools. Educational Management Administration \& Leadership. 2015;43(4):610-625. Available from: https://dx.doi.org/10.1177/ 1741143214523009 .

48) Wanberg CR, Banas JT. Predictors and outcomes of openness to changes in a reorganizing workplace. Journal of Applied Psychology. 2000;85(1):132-142. Available from: https://dx.doi.org/10.1037/0021-9010.85.1.132. 